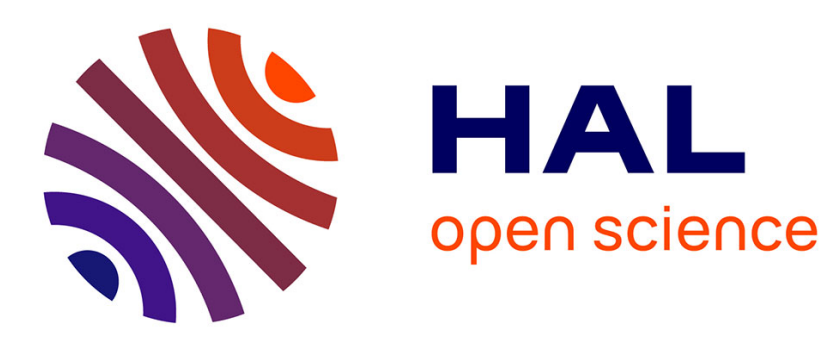

\title{
How fair is pricing perceived to be? An empirical study
}

Charles Raux, Stéphanie Souche, Yves Croissant

\section{To cite this version:}

Charles Raux, Stéphanie Souche, Yves Croissant. How fair is pricing perceived to be? An empirical study. Public Choice, 2009, 139 (1-2), pp.227-240. 10.1007/s11127-008-9390-y . halshs-00372115

\section{HAL Id: halshs-00372115 \\ https://shs.hal.science/halshs-00372115}

Submitted on 4 Nov 2014

HAL is a multi-disciplinary open access archive for the deposit and dissemination of scientific research documents, whether they are published or not. The documents may come from teaching and research institutions in France or abroad, or from public or private research centers.
L'archive ouverte pluridisciplinaire HAL, est destinée au dépôt et à la diffusion de documents scientifiques de niveau recherche, publiés ou non, émanant des établissements d'enseignement et de recherche français ou étrangers, des laboratoires publics ou privés. 


\title{
How fair is pricing perceived to be? An empirical study
}

\author{
Charles Raux*, Stéphanie Souche** and Yves Croissant*** \\ LET, Transport Economics Laboratory \\ (CNRS, Université de Lyon, ENTPE) \\ ISH, 14 av Berthelot, 69363 Lyon, France. \\ *email: charles.raux@let.ish-lyon.cnrs.fr \\ **email: stephanie.souche@let.ish-lyon.cnrs.fr \\ ***email: yves.croissant@let.ish-lyon.cnrs.fr
}

Paper published in Public Choice, Volume 139, Numbers 1-2, pp. 227-240.

http://dx.doi.org/10.1007/s11127-008-9390-y

\begin{abstract}
The perceived fairness of different rules for allocating scarce resources is analysed in two cases: seats on a high speed train and parking spaces in a company car park. Attitudes toward allocation rules depend on context. They vary according to: the educational level of respondents; the type of "good"; and the exceptional or recurring nature of scarcity. Peak pricing, administrative and lottery rules are seen as the most unfair, together with queuing in some cases. The moral rule is considered to be the fairest one, except by more educated people who prefer the compensation rule.
\end{abstract}

$07 / 12 / 2008$ 


\section{Introduction}

Since the work of Pareto (1927), Pigou (1920, 1947) and Samuelson (1947), standard economic theory has established that price is an efficient means of allocating a scarce resource. As Glazer and Lave (1996) and Brueckner (2002) have shown, this applies in all but very rare circumstances.

However, the use of price to eliminate excess demand can be perceived as unfair when it fails to take account of the "reference transaction" defined by Kahneman et al (1986), a concept subsequently used by Vaidyanathan and Aggarwal (2003) and Bolton et al (2003). Frey and Pommerehne (1993), and Oberholzer-Gee and Weck-Hannemann (2002), hold that economists place too much emphasis on pricing as a means of allocation. They argue that ethical considerations should be taken into account when attempting to gain acceptance for policies involving regulation by pricing. Although pricing is the recommended means of regulating congestion (Vickrey 1963), political and social resistance to new pricing measures is also observed in the transport sector (Raux and Souche 2004). There is similar resistance to the introduction of "green taxes" in order to regulate harmful environmental effects (Thalmann 2004),

However, introducing fairness into resource allocation may result in a less efficient outcome (Franciosi et al. 1995 ; Kachelmeier et al. 1991). Oberholzer-Gee (2006) has shown that waiting lines lead ex post to an inefficient allocation of products and services.

So, is the allocation of scarce goods by means of price always perceived as unfair by the population, and if so, to what extent? Analysing how such judgements of fairness develop is particularly important in understanding public attitudes regarding the allocation of scarce resources. These attitudes are an unavoidable part of the public decision-making process and influence final political outcomes.

The literature indicates that there is no clear link between attitudes and actual behaviour (Ajzen 1991; Eagly and Chaiken 1993; Holt and Laury 2002). In any case, our purpose is not to investigate any such link, but rather to explore how the context within which allocation rules are implemented influences the perception of their fairness.

In this paper, we test different rules of allocation empirically. These include lottery, queuing and moral rules, and also other previously untested allocation rules such as a combination of peak pricing with either additional supply or compensation, in order to see if these receive more support than pure regulation by pricing. A positive justice approach is therefore favoured (Zajac 1995; Young 1995; Konow 2003).

Our results differ somewhat from earlier findings reported in the literature. They also show that previously untested allocation rules may be considered as less unfair, or even fairer, than peak pricing on its own. They shed further light on the impact of personal characteristics, type of good and nature of scarcity on the perceived fairness of allocation rules.

The paper is structured as follows. First, we describe a literature survey from which we generated a series of questions for our questionnaire. Then, we present the methodology applied in the study, based on surveys relating to situations in which train seats and parking spaces are scarce. Next, we use an ordered probit model to analyse the respondents' attitudes. Finally, the main findings are presented and discussed. 


\section{Literature survey and hypotheses}

Somewhat provocatively, Frey and Pommerehne (1993) asked the following question: How can the regulation of excess demand by pricing be considered as unfair when economists recommend it as a principle? In a situation where water was scarce, the authors identified and tested several procedures for allocating resources, each of which used a different principle of justice. To ration excess demand, they found that a classical "first come, first served" (i.e., queuing) procedure or an administrative procedure are considered fairer than a pricing procedure which consists of paying more for resources which have become scarce. So, the first question relates to the constant rejection of the use of pricing to allocate scarce resources, hence Question 1: Is the principle of allocating scarce resources by prices always rejected?

One situation relates to whether the situation of excess demand is foreseeable or not. Frey and Pommerehne have shown that people are less averse to rationing demand by pricing in a recurring situation than in an exceptional situation, hence Question 2: Does the nature of scarcity, exceptional or recurrent, influence attitudes to allocation rules?

The question arises whether other procedures would prove more acceptable. Frey and Pommerehne have shown, for example, that allocation by pricing was perceived as being less fair than an arbitrary bureaucratic allocation procedure, but fairer than a random allocation procedure. Taylor et al. (2003) found that in the absence of a pricing system, a lottery is generally more socially acceptable than queuing. According to the economic theory of bureaucracy (Niskanen 1971), the bureaucratic procedure is considered to be intrinsically particularly unfair. Question 3: Are lotteries or bureaucratic allocation more acceptable than allocation by pricing as a means of dealing with excess demand?

Another factor which may influence the perception of allocation by pricing relates to the possibility of controlling the use of revenue. For instance, for Zajac (1995) denial of control is considered unjust in the context of a monopoly power on what is considered as an economic right. Question 4: Does the possibility of controlling the use of revenues from pricing moderate the rejection of allocation by pricing?

With regard to the control of the use of revenue from pricing, given the results of Vaidyanathan and Aggarwal (2003) and Bolton et al (2003), it is interesting to see whether the proposal of additional supply, which would justify the price increase, can modify negative attitudes to allocation by pricing. Question 5: Can providing additional supply, which generates a price increase, make this increase more acceptable?

The question of compensation naturally arises. It has been established since the work of Hicks (1939) and Kaldor (1939) that in the context of a standard cost-benefit analysis, hypothetical compensation can justify a policy as long as the benefits accruing to the winners exceed the losses borne by the losers. So, in principle, effective compensation could counterbalance the rejection of the pricing allocation mechanism. Moreover, according to Zajac (1995), individuals expect to be insured by society against economic loss brought about by economic changes. Lastly, Young (1995) feels it necessary to think about the design of the compensation scheme.

However, it seems that this principle of compensation will be rejected because the "compensated losers" feel that their votes are being bought (the so-called "bribe effect") 
in order for the wealthy to be able to benefit from the goods which are thereby made available (Frey et al. 1996; Frey and Oberholzer-Gee 1996; Kunreuther and Easterling 1996). This is why Oberholzer-Gee and Weck-Hannemann (2002) suggest that compensation should resemble the purchase of votes as little as possible: those who are willing to reduce their consumption of the scarce good should be rewarded in the same "dimension" as the loss because they make a contribution to improving collective welfare. Question 6: Does offering compensation which belongs to the same "dimension" as that whose demand has been removed improve acceptance of allocation by pricing?

A last set of allocation rules represents the classical basis of the "reference transaction" (Kahneman et al 1986). These rules are widely used in all administrative or commercial departments: queuing (or the "first come, first served" procedure) is the basic form of rationing. Barzel (1974) has shown that the redistribution of a good which is limited in quantity through queuing can be costly and does not systematically benefit the poor. Application of a moral rule, for example giving priority to persons with reduced mobility, may be based on Rawls' (1971) two principles of equality of chances and difference. Question 7: Are the rules which form the classical basis of the reference transaction such as queues and a moral rule, universally perceived as fair?

For Konow (2003) justice principles have an independent existence: while the evaluation of justice depends on the context, its principles do not change according to context. This context is broadly defined as the set of historical terms of transaction, the individuals' characteristics, the type of good being distributed and the framing of information. This leads us to Question 8: Does the type of good influence attitudes toward allocation rules?

Last, in relation to these rules of allocation, in particular allocation by pricing, it is important to establish whether an individual's economic situation influences his/her attitude. Weitzman (1977) has shown that the relative efficiency of pricing or rationing for allocating a scarce resource to those who need it most depends on how the need in question and incomes are distributed. According to Sah (1987) the poor would gain more from rationing and the rich from the market. Question 9: Do attitudes vary according to the economic and social situation of individuals?

The above questions are the subject of an empirical investigation using questionnaires in a survey which we shall now describe.

\section{Methodology}

\subsection{The survey and questionnaires}

The survey was conducted in January 2003 and involved face-to-face interviews by professional pollsters of a sample of 400 persons representative of the inhabitants of the Lyon urban area (population 1.2 million). The sample was randomly selected on the basis of quotas (residential location, age groups, gender and occupational status working/non working -). 
Four different "scenarios" were described. Although fictional, these scenarios were grounded in reality (the Paris-Lyon train or parking in urban areas). Various solutions for solving excess demand were proposed and respondents were asked if they found each of the solutions very unfair, essentially unfair, essentially fair or very fair.

Two of the scenarios involved the allocation of seats in situations of excess demand on the high speed train (TGV) between Paris and Lyon $(450 \mathrm{~km}, 2$ hours travel time), which is operated by the public French National Railways Company (SNCF). As a general rule, only passengers with reservations can use this train. The first scenario described an exceptional situation on a Friday evening: as a result of very bad weather (e.g., a snow storm), only one of the three scheduled trains was able to run. The second scenario described a recurring situation of excess demand, in which rising demand on Friday evenings led to complete saturation of the service.

Two other scenarios dealt with the problem of assigning parking spaces in a private company car park in the centre of a major city where parking is very scarce. In one case, the situation was exceptional: construction work lasting several months was necessary in the car park, making two-thirds of the parking spaces temporarily unavailable. In the other case, the situation of excess demand was recurring; the firm was extending its premises by building over part of the existing car park.

Only two scenarios were recounted to each respondent, one about the TGV and the other about parking; in addition, each was told only about the exceptional or the recurring situations. Consequently, each of the four scenarios was described to half the sample. The same allocation rules (i.e., "solutions") were proposed for each of the four scenarios. Moreover, the order in which the solutions were presented was systematically varied for each respondent in order to avoid the bias that might arise if the solutions were always presented in the same order.

The seven allocation rules which were tested are based on the questions listed in the previous section and are set out in Table 1 . 


\begin{tabular}{|c|c|c|}
\hline Allocation rules & $T G V$ train seats & Parking spaces \\
\hline $\begin{array}{l}\text { Peak period pricing with } \\
\text { constant supply }\end{array}$ & Pay an additional charge & Pay an additional charge \\
\hline Moral rule & $\begin{array}{l}\text { Priority is given to persons with } \\
\text { reduced or impaired mobility } \\
\text { (pregnant women, elderly and } \\
\text { handicapped persons) }\end{array}$ & As for train \\
\hline Lottery & $\begin{array}{l}\text { The available seats are attributed } \\
\text { on a lottery basis }\end{array}$ & $\begin{array}{l}\text { The available places are attributed } \\
\text { on a lottery basis }\end{array}$ \\
\hline $\begin{array}{l}\text { Unknown administrative } \\
\text { rule }\end{array}$ & $\begin{array}{l}\text { Tickets inspectors allocate the } \\
\text { available seats }\end{array}$ & $\begin{array}{l}\text { Firm management or workforce } \\
\text { representatives allocate available } \\
\text { places }\end{array}$ \\
\hline Queuing rule & $\begin{array}{l}\text { The train is allowed to fill on a } \\
\text { "first come, first served" basis }\end{array}$ & $\begin{array}{l}\text { The car park is allowed to fill on a } \\
\text { "first come, first served" basis }\end{array}$ \\
\hline Compensation & $\begin{array}{l}\text { Those accepting to take the train } \\
\text { the next day are compensated }\end{array}$ & $\begin{array}{l}\text { Those accepting not to park in the } \\
\text { firm's car park are compensated }\end{array}$ \\
\hline $\begin{array}{l}\text { Peak period pricing with } \\
\text { additional supply }\end{array}$ & $\begin{array}{l}\text { Additional trains are offered which } \\
\text { are paid for by an increase in ticket } \\
\text { price }\end{array}$ & $\begin{array}{l}\text { Additional parking spaces are paid } \\
\text { for by the driver }\end{array}$ \\
\hline
\end{tabular}

Table 1: The seven allocation rules used in the questionnaires

A translation of the exact wording of questionnaires is given in Appendix A.

401 individuals were surveyed, each responding to scenarios about two goods (TGV seats and parking spaces) with regard to the seven allocation rules, i.e. 5614 potential observations, including missing values.

\subsection{Econometric analysis}

The responses in the survey can be considered as ordinal since they can take on the values 1 (very unfair), 2 (unfair), 3 (fair) and 4 (very fair). Thus, the statistical model applied was an ordered probit model (or the "proportional odds model", see McCullagh 1980).

If $Y$ is the response factor with $K$ levels, the model is written:

$$
P(Y \leq k \mid x)=\Phi\left(\theta_{j}-\beta^{\prime} x\right)
$$

where $\Phi$ is the cumulative normal function,

$\theta_{0}=-\infty<\theta_{1}<\cdots<\theta_{K}=\infty$ are the breakpoints,

$x$ is the vector of the explanatory factors and $\beta$ the vector of the unknown parameters.

Since each individual answered a series of seven questions about perceived fairness (one for each allocation rule) for each of the two scenarios, a fixed-effect model could have been considered. However, due to the problem of incidental parameters, it is impossible to estimate a fixed-effect model of this type. A conditional probit model may 
overcome this problem, but all the individual variables would be removed from the specification. As this problem can be circumvented by introducing a random effect (Butler and Moffitt 1982), a random-effect ordered probit model was estimated.

Since the coding of the responses varies from 1 (very unfair) to 4 (very fair), a positive value for a variable coefficient indicates a tendency to consider the proposed rule as fair.

Personal characteristics include gender, age in five groups (under 30 years, between 30 and 39 years, between 40 and 49 years, between 50 and 59 years, 60 years and over), driving license (yes/no), educational level in five groups (no diploma, lower certificate, A-levels, graduate level, post-graduate level), and occupational status in seven groups (small businesses and retailers, senior managers, middle managers, office workers, industrial workers, retired, non-working). Income is a sensitive question with a high non-response rate, but this was circumvented here by using educational level and occupational status as a proxy for income.

\section{Results and discussion}

Table 2 gives an initial overview of differences in the perceived fairness of the different allocation rules for TGV seats and parking spaces.

\begin{tabular}{|c|c|c|c|c|}
\hline \multirow[b]{2}{*}{ Context of scarcity } & \multicolumn{2}{|c|}{ TGV } & \multicolumn{2}{|c|}{ Parking } \\
\hline & exceptional & recurring & exceptional & recurring \\
\hline \multirow{2}{*}{$\begin{array}{l}\text { Peak period pricing with constant } \\
\text { supply }\end{array}$} & $10 \%$ & $10 \%$ & $7 \% *$ & $10 \% *$ \\
\hline & & & $37 \% * *$ & $28 \% * *$ \\
\hline Moral rule & $90 \%$ & $70 \%$ & $96 \%$ & $91 \%$ \\
\hline Lottery & $17 \%$ & $4 \%$ & $17 \%$ & $12 \%$ \\
\hline \multirow[t]{2}{*}{ Unknown administrative rule } & $13 \%$ & $21 \%$ & $8 \% * * *$ & $10 \% * * *$ \\
\hline & & & $13 \% * * * *$ & $14 \% * * * *$ \\
\hline Queuing & $37 \%$ & $33 \%$ & $68 \%$ & $69 \%$ \\
\hline Compensation & $95 \%$ & $80 \%$ & $93 \%$ & $89 \%$ \\
\hline $\begin{array}{l}\text { Peak period pricing with } \\
\text { additional supply }\end{array}$ & n.a. & $29 \%$ & $51 \%$ & $38 \%$ \\
\hline
\end{tabular}

Table 2: Perception of allocation rules in the case of TGV and parking, \% essentially or very fair 
Since there are obvious differences in the perception of the rules, a series of questions naturally arises: does the perception of fairness depend on the type of good concerned (TGV seats versus parking spaces), on the respondents' personal characteristics or on the nature of the scarcity (recurring or exceptional)?

First, the stability of the influence of different variables was tested by comparing a constrained model (for both types of good) with an unconstrained model which was estimated separately for the two goods, namely TGV seats and parking spaces ${ }^{\mathrm{ii}}$. The result of this first test justifies separate estimations for TGV seats and parking spaces.

Next, we tested whether some simplification could be made with regard to respondents' personal characteristics. After several trials, the only personal characteristics retained were educational level (more/less educated) and possession of a driving license (for parking only).

Finally, in order to study potential interactions between the context and the perception of allocation rules, the stability of the coefficients for personal characteristics (education and driving license in the case of parking) and the nature of scarcity (exceptional / recurring) for all seven allocation rules was assessed. Interaction effects with educational level and the nature of scarcity were significant in the case of the TGV while for parking only the interaction effects with education were retained.

The final models estimated for TGV seats and parking spaces are displayed in Table 3.

In both cases the standard deviation of the individual effect was highly significant (see Sigma): this justifies ex post the use of a random effect model. 


\begin{tabular}{|c|c|c|c|c|c|c|}
\hline \multirow[b]{2}{*}{ Variable } & \multicolumn{3}{|c|}{ TGV seats } & \multicolumn{3}{|c|}{ Parking spaces } \\
\hline & Coef. & z-value & $\mathrm{p}$-value & Coef. & z-value & $\mathrm{p}$-value \\
\hline Constant & -0.37 & -3.91 & 0.000 & -0.28 & -3.40 & 0.001 \\
\hline recurring & 0.33 & 2.36 & 0.018 & -0.08 & -1.28 & 0.202 \\
\hline driving_license_no & & & & 0.25 & 2.91 & 0.004 \\
\hline education_no & -0.25 & -1.03 & 0.302 & 0.00 & -0.01 & 0.994 \\
\hline administrative rule & 0.23 & 1.70 & 0.090 & -0.03 & -0.30 & 0.764 \\
\hline lottery & 0.51 & 4.03 & 0.000 & 0.28 & 2.85 & 0.004 \\
\hline peak pricing (pp), additional supply & 0.57 & 3.38 & 0.001 & 1.30 & 12.81 & 0.000 \\
\hline queuing & 1.00 & 8.12 & 0.000 & 1.85 & 19.70 & 0.000 \\
\hline moral rule & 2.66 & 19.51 & 0.000 & 2.82 & 26.27 & 0.000 \\
\hline compensation & 2.94 & 22.78 & 0.000 & 2.70 & 24.93 & 0.000 \\
\hline education_no * administrative rule & 0.30 & 0.78 & 0.438 & -0.28 & -0.68 & 0.497 \\
\hline education_no $*$ lottery & -0.02 & -0.05 & 0.965 & -0.66 & -1.36 & 0.173 \\
\hline education_no * $p p$, additional supply & -0.82 & -1.69 & 0.091 & -0.94 & -2.36 & 0.018 \\
\hline education_no * queuing & 0.26 & 0.87 & 0.387 & 0.13 & 0.40 & 0.690 \\
\hline education_no $*$ moral rule & 0.66 & 1.83 & 0.068 & 0.27 & 0.72 & 0.472 \\
\hline education_no * compensation & -0.53 & -1.50 & 0.134 & -0.68 & -2.15 & 0.031 \\
\hline recurring * administrative rule & -0.27 & -1.41 & 0.158 & & & \\
\hline recurring * lottery & -1.18 & -5.75 & 0.000 & & & \\
\hline recurring * queuing & -0.40 & -2.30 & 0.022 & & & \\
\hline recurring * moral rule & -1.07 & -5.74 & 0.000 & & & \\
\hline recurring * compensation & -1.24 & -6.71 & 0.000 & & & \\
\hline \multicolumn{7}{|l|}{ Threshold parameters for index model } \\
\hline $\mathrm{Mu}(01)$ & 0.99 & 28.53 & 0.000 & 1.03 & 29.28 & 0.000 \\
\hline $\mathrm{Mu}(02)$ & 2.23 & 50.43 & 0.000 & 2.54 & 53.56 & 0.000 \\
\hline \multicolumn{7}{|l|}{ Std. Deviation of random effect } \\
\hline Sigma & 0.30 & 7.40 & 0.000 & 0.38 & 10.15 & 0.000 \\
\hline
\end{tabular}

Table 3: Final models

Since these results are complex to interpret with the inclusion of the various interaction effects, Figure 1 displays the levels of perceived fairness of the allocation rules for each good (TGV / parking) and for each combination of effects, education (yes / no, i.e., more / less educated) and the nature of scarcity (exceptional / recurring), which is only significant for the TGV. 


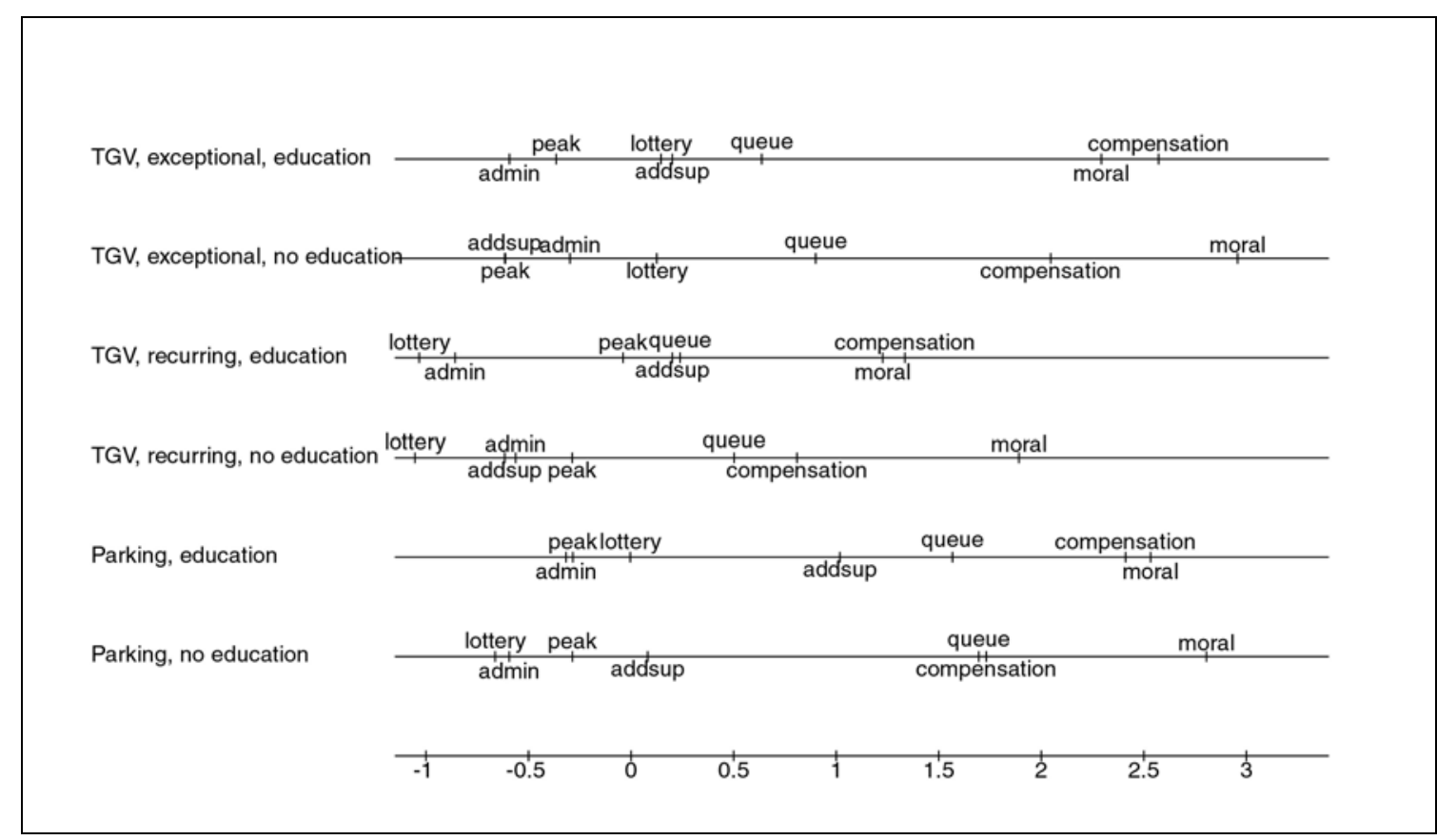

Figure 1: Perceived fairness of allocation rules according to the context

A first striking result emerges from the overview presented in Figure 1, which illustrates the previous statistical results: the perceived fairness of allocation rules depends on the type of good tested, the respondents' personal characteristics and the nature of scarcity with, moreover, interactions between these three categories of variables.

Result 1: It is confirmed that the perception of justice is "context dependent".

However, these variations in perceived fairness aside, the ranking of allocation rules stays roughly the same. The moral rule and the compensation rule are perceived as the fairest in all contexts, for both the TGV and parking, and in situations of both exceptional or recurring scarcity (for the TGV - for parking the nature of scarcity has no influence). The queuing rule is perceived as possessing an intermediate level of fairness. For more educated people, peak pricing with additional supply ("addsup" in Figure 1) achieves as high a score as queuing, while for less educated people the perceived fairness of peak pricing with additional supply is much lower.

Another, expected, result is that peak pricing with constant supply ("peak" in Figure 1), is perceived to be the most unfair. The administrative rule ("admin" in Figure 1) performs as poorly as peak pricing: this differs from the findings of the earlier literature (Frey and Pommerehne 1993), but this involved a context which was different from ours. Finally, the lottery rule performs in general as poorly as the two previous ones, and in some cases worse.

Result 2: While the perceived fairness of allocation rules depends on the context, the ranking of the perception of allocation rules appears to be the same, namely, from the fairest to the most unfair: the moral and compensation rules, followed by queuing and peak pricing with additional supply, and, last, peak pricing with constant supply, the administrative rule and the lottery. This ranking seems to indicate that the principles of justice exhibit a degree of universality. 
An analysis of the different contexts tested in the survey yields some novel results. First, the nature of scarcity influences the fairness judgement. Controlling for educational level, in the case of TGV seats, the perceived fairness of most of the allocation falls when we switch from exceptional to recurrent scarcity, the most striking drop being for the lottery (in Figure 1, compare "TGV, exceptional, education" with "TGV, recurring, education" and "TGV, exceptional, no education" with "TGV, recurring, no education").

There are however two exceptions. The first is the conventional peak pricing rule which is perceived as slightly less unfair when we switch from exceptional to recurring scarcity (this confirms a previous finding by Frey and Pommerehne 1993). The second exception is peak pricing with additional supply for which the judgement is not influenced by the nature of scarcity, again controlling for educational level (in Figure 1, note the position of "addsupp" when comparing "TGV, exceptional, education" with "TGV, recurring, education" and "TGV, exceptional, no education" with "TGV, recurring, no education").

Result 3: The allocation rules, except for the conventional peak pricing rule, are perceived as less fair in a context of recurrent scarcity than in a context of exceptional scarcity. It would seem that in the case of recurring scarcity increasing supply is generally preferred to restricting demand.

Moreover, an increase in supply may alter the perception of peak pricing. Peak pricing with additional supply is not always as strongly rejected as peak pricing with constant supply, especially in the case of parking (see Figure 1). Peak pricing with additional supply may reduce opposition among respondents, or even divide those for and those against into two approximately equal groups (see Table 2, $51 \%$ in the case of parking / exceptional).

Furthermore, the way revenues are used may alter the attitudes about peak pricing, as shown by the example of parking. Peak pricing with constant supply is perceived as being significantly less unfair in the case of parking when the revenue derived from pricing is handed over to the Works Counciliii (28\% in the case of recurring scarcity, $37 \%$ in the case of exceptional scarcity, see Table 2) than when this revenue goes into the firm's coffers $(10 \%$ in the case of recurring scarcity, $7 \%$ in the case of exceptional scarcity).

Result 4: Negative attitudes towards peak pricing with constant supply can be significantly moderated by how the revenue is allocated. The increase in supply may also reduce, in some cases significantly, the opposition to peak pricing.

Meanwhile, personal characteristics play a role as educational level definitely influences the perceived fairness of the allocation rules. Controlling for the type of good and the nature of scarcity, less educated people consider the moral and queuing rules to be fairer when compared with more educated people, while the opposite applies for the compensation and the peak pricing with additional supply rules.

The compensation rule and the moral rule compete to be the fairest, as shown in Figure 1. However, less educated people definitely rank compensation second after the moral rule, while more educated people rank compensation at about the same level as the moral rule. 
This may indicate an aversion to market instruments on the part of the less educated and, as far as compensation is concerned, a "bribe effect" as referred to in the literature survey above.

Another lesson relates to the additional supply mentioned above: providing additional supply in the context of peak pricing can also be regarded as a form of compensation. Our results show that it is perceived as being extremely indirect and support for this type of solution is much lower than support for direct compensation (compare "addsup" and "compensation" in Figure 1).

Result 5: Within the overall ranking of allocation rules, less educated people rank the moral and queuing rules higher than more educated people. The latter rank the compensation and peak pricing with additional supply rules higher than less educated people. Lower education may indicate an aversion to market instruments.

Are moral and queuing rules always the fairest? The results confirm that the moral rule is part of the reference transaction (Kahneman et al 1986) as it is considered the fairest across all contexts. However, the moral rule alone (i.e., giving priority to mobilityimpaired individuals and so on) does not entirely solve the issue of allocating parking spaces or TGV seats.

In the case of queuing, our findings are different. More educated and less educated people both consider queuing to be reasonably fair in the case of parking (see Figure 1). In the case of the allocation of TGV seats in a recurring situation, for more educated people the queuing rule obtains as poor a score as the peak pricing with constant supply rule. This runs counter to the conclusions reached by the earlier empirical literature (although in other contexts), where the traditional "first come, first served" procedure is greatly preferred to pricing. In the case of the TGV, the reference transaction is based on a seat reservation system: cancelling the advance reservation system (which is of course just another queuing system) in order to replace it at short notice by instant queuing is negatively perceived.

Result 6: While the moral rule is perceived as the fairest in all contexts and can be considered to belong to the reference transaction, the same cannot be said for queuing. This suggests that the reference transaction may vary according to the context.

\section{Conclusion}

Our results confirm that the perception of justice is "context dependent". Across the different contexts a general ranking of the perception of allocation rules is found, from the fairest to the most unfair: the moral and the compensation rules, then the queuing and the peak pricing with additional supply rules, and finally the peak pricing with constant supply, the administrative and the lottery rules.

Our results differ to some extent from previous work which found that administrative allocation was perceived to be fairer than the pricing solution, but this work involved different contexts. It would seem that attitudes towards this "bureaucratic" allocation depend on how much confidence people have in those managing it.

The moral rule is judged to be very fair in all cases while, unexpectedly, this is not true for queuing. The reference transaction may lead to a perception of queuing as unfair, for 
example in the case of a service which is generally accessed by means of an advance reservation system.

Moreover, these attitudes may vary according to the nature of scarcity. In the case of recurring scarcity for the TGV seats, the allocation rules are perceived to be less fair than in the case of exceptional scarcity.

The negative attitude toward peak pricing is not intractable: people's opposition can be reduced if they can influence the way the revenues are used. Accompanying a price increase with an additional service or infrastructure may reduce opposition in the case of some goods in the same way as the right to influence the use of revenue. Nevertheless, the negative attitudes subsist.

Last, our results allow us to moderate conclusions which are on first view rather pessimistic from the economic standpoint. They show that compensation, which is clearly considered to be fair, can radically modify attitudes of rejection of the pricing instrument.

However, educational level has a definite influence on fairness judgements about the allocation rules. Less educated people consider the moral and queuing rules to be fairer and the compensation rule and peak pricing with additional supply to be less fair when compared to more educated people. Lower education may indicate an aversion to market instruments.

Again, as stated in the introduction, these are attitudes which may differ from actual behaviour. However, these attitudes are an unavoidable part of the public decisionmaking process regarding the regulation of scarce resources.

\section{Acknowledgements}

Research grant from the ADEME (French Agency for Environment Protection and Energy Conservation, Agreement no. 0003 040) is acknowledged. We also gratefully acknowledge the comments by anonymous referees and the Editor-in-Chief of Public Choice. 


\section{Appendix A: The questionnaires}

\begin{tabular}{|c|c|c|c|}
\hline \multicolumn{2}{|l|}{ TGV Exceptional situation } & \multicolumn{2}{|c|}{ TGV Recurring situation } \\
\hline \multicolumn{2}{|c|}{$\begin{array}{l}\text { This takes place in Paris, in the "Gare de Lyon" } \\
\text { railway station, on a Friday evening in January. } \\
\text { Three TGVs are scheduled to run in the } \\
\text { evening, and the passengers are waiting for } \\
\text { theirs in order to travel back to Lyon. They } \\
\text { have all reserved and paid for their seats. The } \\
\text { SNCF announces that because of an } \\
\text { exceptional snowstorm only one TGV will be } \\
\text { running (on safety grounds the number of } \\
\text { passengers boarding a TGV must not exceed } \\
\text { the number of seats). }\end{array}$} & \multicolumn{2}{|c|}{$\begin{array}{l}\text { This takes place on the TGV line between Paris } \\
\text { and Lyon. Demand on this line is such that the } \\
\text { trains are systematically full on Friday } \\
\text { evenings with standing passengers. The SNCF } \\
\text { wants to put a stop to this situation on safety } \\
\text { grounds. There must be no more standing } \\
\text { passengers. }\end{array}$} \\
\hline \multicolumn{4}{|c|}{$\begin{array}{l}\text { There are a number of different ways the available seats could be allocated. } \\
\text { I will describe each of them to you and then I want you to tell me if you consider it to be very unfair, } \\
\text { essentially unfair, essentially fair or very fair. }\end{array}$} \\
\hline $\begin{array}{l}\text { The available seats are given to people } \\
\text { who are willing to pay an exceptional } \\
\text { supplement of } 30 \text { Euros }\end{array}$ & \multicolumn{2}{|c|}{$\begin{array}{l}\mathrm{v} 2 \\
\text { Peak period pricing } \\
\text { with constant supply }\end{array}$} & $\begin{array}{l}\text { Passengers travelling between } 3 \mathrm{pm} \\
\text { and } 9 \mathrm{pm} \text { on Fridays have to pay a } \\
\text { supplement of } 30 \text { Euros to encourage } \\
\text { people to travel at other times }\end{array}$ \\
\hline $\begin{array}{l}\text { Priority for seats is given to elderly } \\
\text { persons, pregnant women and people } \\
\text { travelling with young children. }\end{array}$ & \multicolumn{2}{|c|}{$\begin{array}{l}\mathrm{v} 3 \\
\text { Moral rule }\end{array}$} & $\begin{array}{l}\text { Priority for seats is given to elderly } \\
\text { persons, pregnant women and people } \\
\text { travelling with young children. }\end{array}$ \\
\hline $\begin{array}{l}\text { The available seats are allocated by } \\
\text { holding a lottery. }\end{array}$ & \multicolumn{2}{|c|}{$\begin{array}{c}\mathrm{v} 4 \\
\text { Lottery }\end{array}$} & $\begin{array}{l}\text { The reservation system is withdrawn } \\
\text { and the seats are allocated by holding } \\
\text { a lottery among the waiting } \\
\text { passengers. }\end{array}$ \\
\hline $\begin{array}{l}\text { The ticket inspectors allocate the } \\
\text { available seats as they think best. }\end{array}$ & \multicolumn{2}{|c|}{$\begin{array}{c}\mathrm{v} 5 \\
\text { Unknown } \\
\text { administrative rule }\end{array}$} & $\begin{array}{l}\text { The ticket inspectors allocate the } \\
\text { available seats as they think best. }\end{array}$ \\
\hline $\begin{array}{l}\text { The passengers wait until the train } \\
\text { arrives and are then allowed to board } \\
\text { the train until all the seats are taken. }\end{array}$ & \multicolumn{2}{|c|}{$\begin{array}{c}\text { v6 } \\
\text { Queuing }\end{array}$} & $\begin{array}{l}\text { The reservation system is withdrawn } \\
\text { and passengers are allowed to board } \\
\text { the train until all the seats are taken. }\end{array}$ \\
\hline $\begin{array}{l}\text { SNCF offers to provide a night in a } \\
\text { hotel }+ \text { compensation of } 30 \text { Euros to } \\
\text { those who are willing to delay their } \\
\text { departure until the next day. }\end{array}$ & \multicolumn{2}{|c|}{$\begin{array}{c}\mathrm{v} 7 \\
\text { Compensation }\end{array}$} & $\begin{array}{l}\text { Passengers who are willing to leave } \\
\text { before } 3 \mathrm{pm} \text { or after } 9 \mathrm{pm} \text { pay } 15 \\
\text { Euros less for their ticket. }\end{array}$ \\
\hline- & \multicolumn{2}{|c|}{$\begin{array}{c}\mathrm{v} 8 \\
\text { Peak period pricing } \\
\text { with additional supply }\end{array}$} & $\begin{array}{l}\text { The SNCF buys } 5 \text { additional TGVs } \\
\text { and finances them by charging } 15 \\
\text { Euros more for tickets on Friday } \\
\text { evening. }\end{array}$ \\
\hline
\end{tabular}

Proposals were rotated for each person surveyed in order to avoid systematic bias due to the order of presentation. 


\section{Parking}

Exceptional parking situation: This takes place in a large firm whose staff commute to work by car practically every day. The company has a sufficiently large staff car park on its premises. The firm in question is located in the city centre, where parking is very difficult. In the whole district around the firm people take several minutes to find a parking space, and when they find one it is frequently a long way away and parking is expensive (20 Euros per day), and the police systematically issue parking fines. The firm needs to carry out building work lasting 6 months in its car park. As a consequence, 2 out of 3 parking spaces will be unavailable during this period.

Recurring parking situation: This takes place in a large firm whose workforce commutes to work by car practically every day. The company has a sufficiently large staff car park on its premises. The firm in question is located in the city centre, where parking is extremely difficult. In the whole district around the firm people take several minutes to find a parking space, and when they find one it is often a long way away. In addition, parking is expensive (20 Euros per day) and the police systematically issue parking fines. The firm is expanding and the only way it can do so is to build on the existing car park. As a consequence, 2 out of 3 parking spaces will be permanently withdrawn.

There are a number of different ways the remaining spaces could be allocated. I will describe each of them to you and then I want you to tell me if you consider it to be very unfair, essentially unfair, essentially fair or very fair...

The places are given to those who are willing to pay 15 Euros per day, and this revenue is handed over to the firm.

$\mathrm{v} 11$

Peak period pricing with constant supply $\left(M F^{*}\right)$

or

The places are given to those who are willing to pay 15 Euros per day, and this revenue is handed over to the Works Council.

$\mathrm{v} 12$

Peak period pricing with constant supply $\left(W C^{* *}\right)$

then

Priority for places is given to pregnant women, staff with disabilities and those practising car sharing.

The parking spaces are allocated by lottery v14

The management allocates places as it thinks best

\begin{tabular}{|l|c|} 
& $\begin{array}{c}\text { Unknown administrative } \\
\text { rule (MF*) }\end{array}$ \\
\hline The Work's Council allocates places as it thinks best & $\begin{array}{c}\text { v17 } \\
\text { Unknown administrative } \\
\text { rule (WC**) }\end{array}$ \\
\hline $\begin{array}{l}\text { There are no reserved places and the car park is left to fill up naturally every } \\
\text { morning }\end{array}$ & $\begin{array}{c}\text { v18 } \\
\text { Queuing }\end{array}$ \\
\hline $\begin{array}{l}\text { The firm offers to pay half the bus fare of staff who stop commuting by car } \\
\text { v19 }\end{array}$ & $\begin{array}{c}\text { Compensation } \\
\text { v20 }\end{array}$ \\
\hline $\begin{array}{l}\text { The firm rents the additional places that are needed from a private car park and } \\
\text { everyone pays } 10 \text { Euros per day to cover the costs }\end{array}$ & $\begin{array}{c}\text { Peak period pricing with } \\
\text { additional supply }\end{array}$ \\
\hline$* M F=$ Management of the Firm, ** WC $=$ Works Council &
\end{tabular}




\section{References}

Ajzen, I. (1991). The theory of planned behavior. Organizational Behavior and Human Decision Processes, 50, 179-211.

Barzel, Y. (1974). A theory of rationing by waiting, Journal of Law and Economics, 17(1), 73-95.

Bolton, L.E., Warlop, L., Alba, J.W. (2003). Consumer perceptions of (un)fairness, Journal of Consumer Research, 29, 476-491.

Brueckner, J.K. (2002). Airport congestion when carriers have market power, American Economic Review, 92(5), 1357-1375.

Butler, J. S., Moffitt, R. (1982). A Computationally Efficient Quadrature Procedure for the One-Factor Multinomial Probit Model. Econometrica, 50(3), 761-764.

Eagly, A.H., Chaiken, S. (1993). The psychology of attitudes, Fort Worth, TX : Harcourt Brace Jovanovich.

Franciosi, R., Kujal, P., Michelitsch, R., Smith, V., Deng, G. (1995). Fairness : effect on temporary and equilibrium prices in posted-offer markets, The Economic Journal, 105, 938-950.

Frey, B.S., Oberholzer-Gee, F. (1996). Fair Siting Procedures: An Empirical Analysis of Their Importance and Characteristics, Journal of Policy Analysis and Management, 15(3), 353-376.

Frey, B.S., Oberholzer-Gee, F., Eichenberger, R. (1996). The old lady visits your backyard: a tale of morals and markets, The Journal of Political Economy, 104(6), 1297-1313.

Frey, B.S., Pommerehne, W.W. (1993). On the fairness of pricing - an empirical survey among the general population, Journal of Economic Behavior and Organisation, 20, 295-307.

Glazer, A., Lave, C. (1996). Regulation by prices and by command, Journal of Regulatory Economics, 9(2), 191-197.

Hicks, J. (1939). The Foundations of Welfare Economics, Economic Journal, 49, 696712.

Holt, C.A., Laury, S.K., (2002). Risk Aversion and Incentive Effects, American Economic Review, 92(5), 1644-1655.

Kachelmeier, S.J., Limberg, S., Schadewald, M.S. (1991). Fairness in markets: a laboratory investigation, Journal of Economic Psychology, 12, 447-464.

Kahneman, D., Knestsch, J.L., Thaler, R. (1986). Fairness as a constraint on profit seeking: entitlements in the market, American Economic Review, 76(4), 728-741.

Kaldor, N. (1939). Welfare propositions in economics and interpersonal comparisons of Utility, Economic Journal, 49, 549-552.

Konow, J. (2003). Which is the fairest one of all ? A positive analysis of justice theories, Journal of Economic Literature, 41(4), 1188-1239.

Kunreuther, H., Easterling, D. (1996). The role of compensation in siting hazardous facilities, Journal of Policy Analysis and Management, 15, 601-622.

McCullagh, P. (1980). Regression Models for Ordinal Data. Journal of the Royal Statistical Society. Series B (Methodological), 42(2), 109-142.

Niskanen, W.A. (1971). Bureaucracy and representative government, Chicago : Aldine, Atherton.

Oberholzer-Gee, F. (2006). A Market for Time. Fairness and Efficiency in Waiting Lines, Kyklos, 59(3), ) 427-440. 
Oberholzer-Gee, F., Weck-Hannemann, H. (2002). Pricing road use: politico-economic and fairness considerations, Transportation Research Part D, 7, 357-371.

Pareto, V. (1927). Manuel d'Economie Politique, Paris : Girard.

Pigou, A.C. (1920). The Economics of welfare, $4^{\text {th }}$ edition, London: Macmillan.

Pigou, A.C. (1947). Economy progress in a stable environment, Economica, New Series, $14,180-188$.

Raux, C., Souche, S. (2004). The acceptability of urban road pricing: a theoretical analysis applied to experience in Lyon, Journal of Transport Economics and Policy, 38(2), 191-216.

Rawls, J. (1971). A Theory of Justice, Cambridge, Harvard University Press.

Sah, R.K. (1987). Queues, rations, and market: comparisons of outcomes for poor and the rich, The American Economic Review, 77(1), 69-77.

Samuelson, P-A. (1947). Foundations of Economic Analysis, Harvard Economic Studies $L X X X$, Cambridge: Harvard University Press.

Taylor, G.A., Tsui, K.K.K., Zhu, L. (2003). Lottery or waiting-line auctions?, Journal of Publics Economics, 1313-1334.

Thalmann, P. (2004). The public acceptance of green taxes: 2 million voters express their opinion, Public Choice, 119, 179-217.

Vaidyanathan, R., Aggarwal, P. (2003). Who is the fairest of them all? An attributional approach to price fairness perceptions, Journal of Business Research, 56, 453-463.

Vickrey, W. (1963). Pricing in urban and suburban transport, American Economic Review: Papers and Proceedings, 53(2), 452-465.

Weitzman, M.L. (1977). Is the price system or rationing more effective in getting a commodity to those who need it most?, Bell Journal of Economics, 8, 517-524.

Young, H.P. (1995). Equity. In theory and practice, New Jersey: Princeton University Press .

Zajac, E.E. (1995). Political economy of fairness, Cambridge: The MIT Press.

\footnotetext{
${ }^{\mathrm{i}}$ The full questionnaire (in French) can be obtained from the authors. The survey was conducted by the Lyon-based consultancy Tremplin.

ii Detailed information on these intermediate tests is available from the authors upon request.

iii The Works Council ("Comité d'Entreprise") is a body is elected by the workforce of the firm and therefore assumed to represent its interests.
} 